\title{
TECHNOCRATIC GOVERNMENT AND ECONOMIC POLICY
}

Despina Alexiadou

University of Strathclyde

Forthcoming at the Oxford Research Encyclopedia of Politics, Ed. William Thompson. New York: Oxford University Press

\section{Summary}

The recent surge in the appointments of technocrats to the top economic portfolios of finance, and even the formation of fully technocratic governments in Europe raises questions regarding the role of technocrats and technocratic governments in economic policy in democracies. Who are the technocrats? Why are they appointed in the first place? What is their impact on economic policy and finally what their sources of policy influence?

Keywords: technocracy; technocratic; Europe; European Union; economic policy 


\section{Introduction}

A record number of news articles and editorials have been written in the press according to Lexis Nexis since 2011, the year that both Greece and Italy were governed by technocratic led governments to handle the unprecedented financial and political crises. The elevated interest in the role of technocracy in public life has since remained rather high, compared to earlier years, as one can clearly see in Figure 1. While the role of technocrats in democracies is hotly debated among journalists and policymakers, we have limited systematic knowledge about the role of technocrats in democracies and more specifically in governments' economic management.



Technocrats have held prominent positions in governments, especially during periods of economic and political crises. Since 2009 the number of technocrat finance and employment 
cabinet ministers more than doubled in Europe (Alexiadou and Gunaydin 2015). Recently, a former Ukranian technocrat economics minister openly endorsed a fully technocratic government "free from political connections' as the best way to ensure the country proceeds with the reforms that started since the 2014 revolution (Buckley 2016).

Furthermore, technocratic governments and technocrat cabinet ministers are not unique to Europe. Technocrats and technopols, liberalized the labour and capital markets during the 1980s and 1990s debt crises in many Latin American countries with lasting effects in the countries economies and polities (Roberts 2017; Dargent 2015).

What's the role of technocrats and technocratic governments in economic policy? Do technocrats affect the economy? Do their appointments have long-term effects in economic policymaking? Do they adopt policies that are in line with democratic mandates or do they have an influence above and beyond their mandate? And why are technocrats appointed in the first place?

There questions have only recently started to enter the scholarly debate, despite earlier treatments from scholars who study economic reforms and democratic transitions in Latin America (Santiso 2003; Schneider 1998; Joignant 2011). The lack in scholarly work that examines the role of technocrats is puzzling given the plethora of opinions expressed in the media about the role of technocrats in todays' democratic societies (Rampell 2011; Harford 2017) and the elevated interest in technocrats and technocratic governments in the press. For example, non-elected experts are often referred to as technocrats, but so is Hillary Clinton, the 2016 US presidential candidate, former first lady and elected senator for decades. 
This essay has two main goals. First, to clearly discuss the different definitions of technocracy and technocrats, thus providing a road map to the debates on technocracy. Second to review the literature on the role of technocrats in economic policymaking in democracies. The essay concludes with suggestions for future research regarding the role of technocracy in economic policy.

\section{Defining Technocracy, Technocrats, and Technopols}

Who is a technocrat? To assess the role of technocrats in policy we need to be clear about how we define technocrats and technocratic governments. There are three substantially different ways of defining technocrats.

The most encompassing definition of a technocrat is one that includes all experts who are involved in the policymaking process of the government. These could be elected politicians with policy expertise, cabinet ministers or advisors appointed to the cabinet straight from the industry or academia, as well as permanent bureaucrats in various government departments and agencies, such as central bank governors. This definition rests on the premise that when experts take on political roles, they become technocrats (Meynaud 1964). Scholars who use this definition of technocracy are primarily interested in the effects of policymakers' education and professional experience on policy choices and outcomes (Alexiadou 2016; Chwieroth 2007; Christensen 2017; Hallerberg and Wehner 2017; Kaplan 2017; Adolph 2013). The focus is on policymakers' policy preferences and way of thinking, which are independent of their career incentives. A professor of economics or a central banker who holds a $\mathrm{PhD}$ in economics from a top US school will have similar preferences and will make 
similar policy choices as a cabinet minister who is a professional politician and has the same educational background.

An alternative, more restrictive definition of technocrats is one that clearly separates policymakers' expertise from their career incentives. According to this definition, an elected politician with clear political ambitions who has policy expertise, or else a technopol, is different from a non-elected expert, or a technocrat, who is appointed to an executive position. Specifically, according to Joignant (2011) the confusion in the interchangeable use of the terms technopols and technocrats is due to the fact that scholars assign a great importance to policymakers' university credentials and 'tech' resources. "However, this ignores the fact that a technopol also has political resources, generally in the form of previously held positions of formal power in a political party or parties before joining the government, which is precisely not a characteristic of a technocrat"'(Joignant 2011).

On a similar line of thought, McDonnell and Valbruzzi (2014) define a technocrat as a prime minister or a minister who "at the time of his/her appointment to government, he/she: (1) has never held public office under the banner of a political party; (2) is not a formal member of any party; (3) is said to possess recognized non-party political expertise which is directly relevant to the role occupied in government."

For Joignant (2011) clearly separating technocrats from technopols is crucial because technopols possess political resources that technocrats do not. For McDonnell and Valbruzzi (2014), separating technocrats from partisans is crucial for identifying policymakers' underlying policy preferences since partisans align with their formal party, unlike 
technocrats. This is after all why technocratic governments raise questions of accountability and representation (Pastorella 2016).

Clearly differentiating technocrats from technopols is further justified by the fact that policymakers' career incentives directly affect their commitment to policy reforms. While partisan preferences are crucial for identifying the direction of policy change, commitment to certain set of reforms is strongly influenced by policymakers' career incentives. This argument builds on work from Alesina and Tabellini (2007), Adolph (2013) and Alexiadou (2016) that argue that career incentives strongly affect policymakers' policy effectiveness.

According to Alesina and Tabellini (2008), a policymaker's effectiveness to implement a policy reform $y_{1 t}$ is a function of her effort, $a_{t}$ and ability, $\eta_{t}$ :

$$
y_{1 t}=\eta_{t}+a_{t}
$$

A technopol's ability or skill changes slowly and is partly known to the prime minister from past performance. An experienced politician who holds a $\mathrm{PhD}$ in economics would score high on her ability to formulate economic policy, but her commitment to implement a policy that is politically unpopular might be questioned. In other words, while she would score high on ability, she would score low on effort. In contrast, a technocrat would score high both on technical skill and on effort to the extent that her personal cost for adopting unpopular measures is low. Therefore, two cabinet ministers with equal expertise in economics can differ in the effort they put into the task of policy reform depending on their career concerns (Alexiadou 2015, 2016; Blondel 1991; Alesina and Tabellini 2008; Alexiadou and Gunaydin 2015; Adolph 2013). This not to say that technocrats will be more effective in policy reform than technopols. That is an empirical question, as political experience and position in the 
party are crucial factors for being an effective policymaker as argued by Joignant (2011) and shown by Alexiadou $(2015,2016)$ and Jochimsen and Thomasius (2014).

It is important to note here that the more restrictive definitions of technocrats typically also only refer to appointees to the executive branch and do not include permanent bureaucrats. While permanent bureaucrats can have substantial policy influence particularly when there is a large degree of delegation of policy to bureaucrats, such as to politically independent central bankers (Bodea and Hicks 2015) or to influential ministerial departments such as the departments of finance (Christensen 2017), in most instances the restrictive definition of technocrats is reserved for cabinet ministers that have a direct control of economic policy (McDonnell and Valbruzzi 2014; Pinto, Cotta, and Almeida 2017).

It is this latter, more restrictive definition of technocrats that has led scholars to talk about technocratic governments. While the term technocrat should not be confused with technocratic governments, technocratic governments are defined as those governments that primarily consist of non-elected experts. According to McDonnell and Valbruzzi (2014) technocratic governments are governments whose cabinet ministers are mostly technocrats, and/or when the prime minister is a technocrat. In contrast, a cabinet that mostly consists of party representatives but includes a few non-elected experts, or technocrats, is not a technocratic government. Importantly, a government whose cabinet ministers are in their majority policy experts and are also elected members of the parliament are not technocratic governments. These should be best described as expert or diploma governments (Bovens and Wille 2017). It is not surprising that fully technocratic governments are quite rare and tend to form during periods of economic and political crises (Pastorella 2016). 
None of the definitions above refer to technocracy as "a system of governance in which technically trained experts rule by virtue of their specialized knowledge and position in dominant political and economic institutions" (Fischer 1990). This broader definition of technocracy is of importance for policy outcomes and is one that has been central in academic and public debates, alike (Rosanvallon 2011; Bickerton and Accetti 2017; Berman 2017). For example, 2016 will be remembered as the year that voters rejected technocracy for populism. With two percentage points majority, British voters defied the warnings of experts and rejected the technocratic European Union, choosing Brexit. Five months later, Americans elected Donald Trump, rejecting Hillary Clinton’s ‘liberal technocracy’ (Accetti 2016; Savage 2017). Yet, considering politicians who rely on technical advice to formulate policy, such as Hillary Clinton, as technocrats is at the very least confusing. In contrast, according to the restrictive definition of technocrats, Macron, the newly elected French president, could be considered as a technocrat presidential candidate. At the time of his election, Macron was a former investment banker and economics minister who had never held elective office.

Finally, technocrats should not be confused with non-partisans. There is an important literature on the appointments of non-partisan cabinet ministers, also known as outsiders (Camerlo and Perez-Linan 2015) that is motivated by the large percentage of non-elected cabinet ministers appointed in presidential regimes (Amorim and Samuels 2010; MartinezGallardo and Schleiter 2015). While sometimes these non-partisans are referred to as technocrats, one has to be careful to not use the two terms interchangeably, especially if the goal is to understand the role of technocrats in economic policy. Non-partisans include both technocrats and loyal to the president outsiders. Yet, the logics of appointing one over the other are diametrically different. Loyal outsiders are loyalists to the president and thus faithful agents of the president. In contrast, a technocrat is a policymaker with strong policy 
convictions who values policy more than office, and is hard to control (also known as an “ideologue") (Alexiadou 2015, 2016).

\section{Technocrats and Their Role in Economic Policy}

What's the role of technocrats in shaping economic policy? Does it matter whom presidents or prime ministers appoint as their finance and economics ministers for policy outcomes? This question has important implications for representation and policy outcomes as long as technocratic policy solutions contradict the government's mandate. If technocrats implement the government's partisan agenda, then whom prime ministers appoint makes no difference in policy outcomes. If, however technocrats, who are appointed to positions of power, instead set the policy agenda, then their appointments have significant implications for both policy and representation.

To theorise and examine the role of technocrats we first need to identify both technocrats' policy preferences and their source of power. Why would an appointee or an agent want and be able to formulate policy against the preferences of her principal? A typical assumption within comparative politics is that prime ministers or presidents appoint policymakers who are close to their own, their party's or their government's policy preferences (Bäck, Debus, and Müller 2016). Under this assumption, it should not matter if a prime minister chooses a loyal partisan or a technocrat. Since the prime minister appoints this minister and has the power to sack her at any point, then cabinet ministers fulfil their principal's policy agenda. In parliamentary systems, in particular, where representation runs through a long chain of delegation from voters to policymakers, the principal-agent relationship is fundamental for democratic representation (Strom 2000). Yet, ministerial appointments are a lot more complex than often assumed as they often fulfil multiple political and policy-related reasons 
that have little to do with ministers' policy mandates (Dowding and Dumont 2009; Alexiadou 2016). Consequently, cabinet ministers, and even bureaucrats, do not always faithfully represent their principals (Bergman et al. 2003).

To sum up, in order to study the policy effects of technocrats, above and beyond what their masters want, we need first to be able to identify their policy preferences and second why and how they are able to push forward their agenda. In the following two sections I will discuss both these necessary conditions for policy influence.

\section{Technocrats and Ideology}

Often, technocrats are considered ideologically 'neutral' as they are non-partisans. Yet, technocracy can never be politically neutral (Fischer 1990) to the extent that policy changes have direct distributional and re-distributional consequences. Consider for example the Dutch technocrat minister for employment, Aart Jan de Geus who was appointed by the Christian democrat prime minister in the early two-thousands. De Geus was neither a party member nor a member of parliament, and this is exactly the reason he was selected for this job, according to him (personal interview, June 2011). He was explicitly asked by the prime minister to deliver reforms that were not favored by the "old generation of Christian democrats in the party”. He needed someone who had personally worked with the social partners- De Geus was the vice-president of the Christian trade union, CNV- and who would be determined to reform the disability system. According to De Geus the reason he succeeded in his reforms was because personal attacks to his personal reputation would not stop his reform efforts. He "could understand that kind of pressure because he could understand the rules of the game". He further added that "if you start from outside there are no obligations, no open bills to other people. You start with a blank notebook". 
De Geus's policy preferences were largely in line with a lot of policy prescriptions made by the OECD (Organization for Economic Cooperation and Development). Were they neutral? Not quite. They were rather liberal from the point of view of the Dutch trade unions (Alexiadou 2016). At the same time, they were more moderate than what many partisan ministers from the more right-wing VVD supported (Alexiadou 2016).

When it comes to economic policy in particular, the shift in economic thought from NeoKeynesian economics to Neo-Classical economics in the seventies, has meant that technocrats, especially those who come from the banking and finance sector but even economists trained in top US departments, are further to the right in their ideological placement than the average Social-democrat or Christian-democrat party member. Since the nineteen eighties there is a strong consensus within the economics discipline about the superiority of market conforming policies (Fourcade 2009). These policies typically include "the deregulation of product markets, labour markets, and financial markets; the liberalization of trade; the corporatization and privatization of state entities; and low-rate, broad-base reform (Christensen 2017) Moreover, influential governmental think-tanks such as the OECD, have been calling for labour-market liberalization and lower income tax for the last three decades (OECD 2010). If technocrats, defined as non-elected experts, are primarily drawn from the ranks of economists who work in academia, supra-national governmental institutions or the banking sectors then they are likely to share similar, market-conforming preferences (Santiso 2003). While these policy prescriptions often go against entrenched political interests (Christensen 2017; Dargent 2015), they should not be considered as apolitical. Moreover, often technocrats are drawn directly from the financial industry. In this 
case, one has to be concerned not only about technocrats' 'academic bias' but also about these individuals' own industry's interests (Jopson 2017).

Using data from Alexiadou (2016), I provide an overview of the professional background of finance ministers who were never elected compared to the professional background of all finance ministers in parliamentary 18 West European countries in Figures 2 and 3 respectively. It is clear that the vast majority of non-partisan ministers have a background in banking, finance or economics, therefore can be defined as technocrats.

[insert Figure 2 here]

Figure 2: Background of finance ministers who were never in elective office

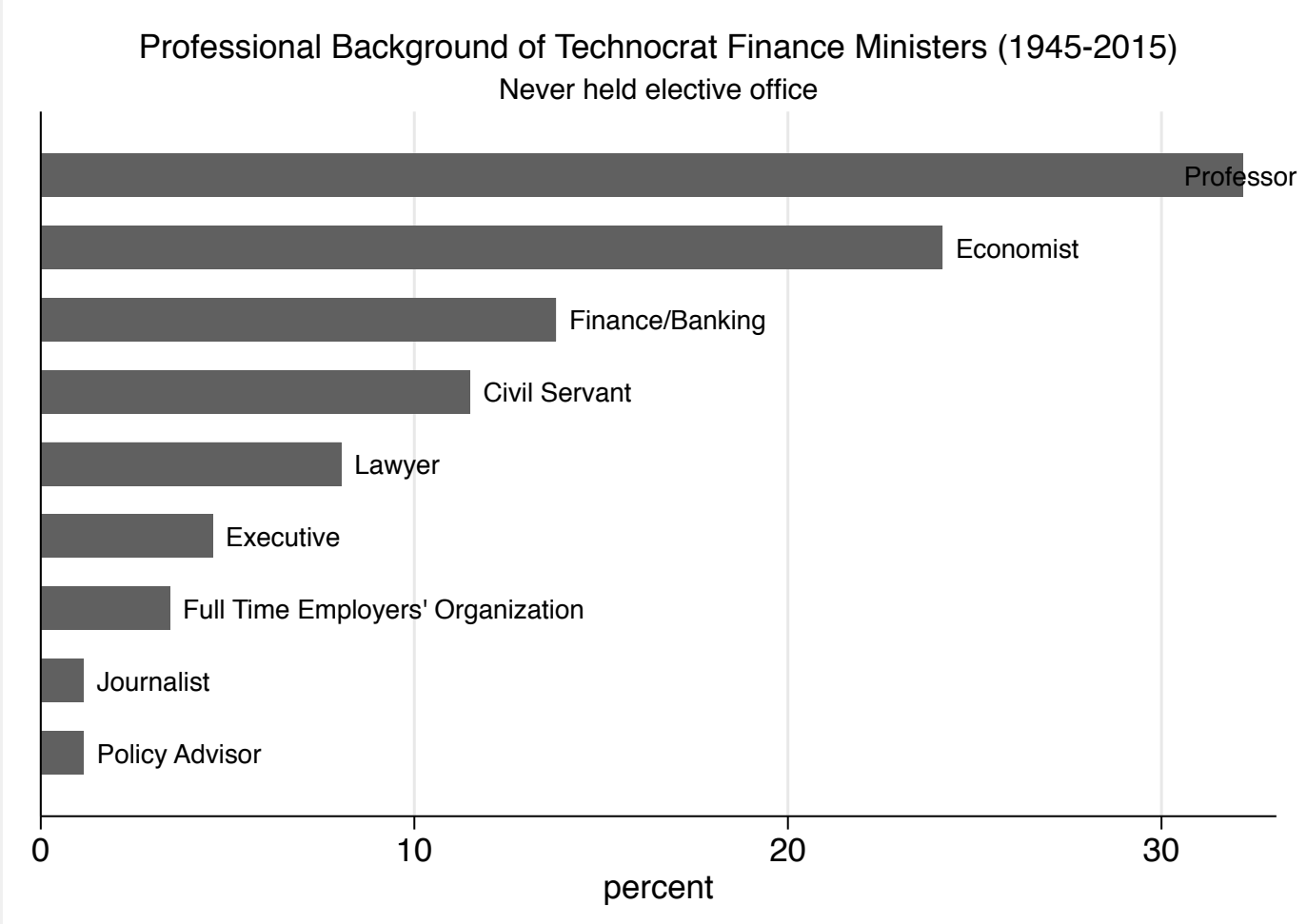

[insert Figure 3 here] 


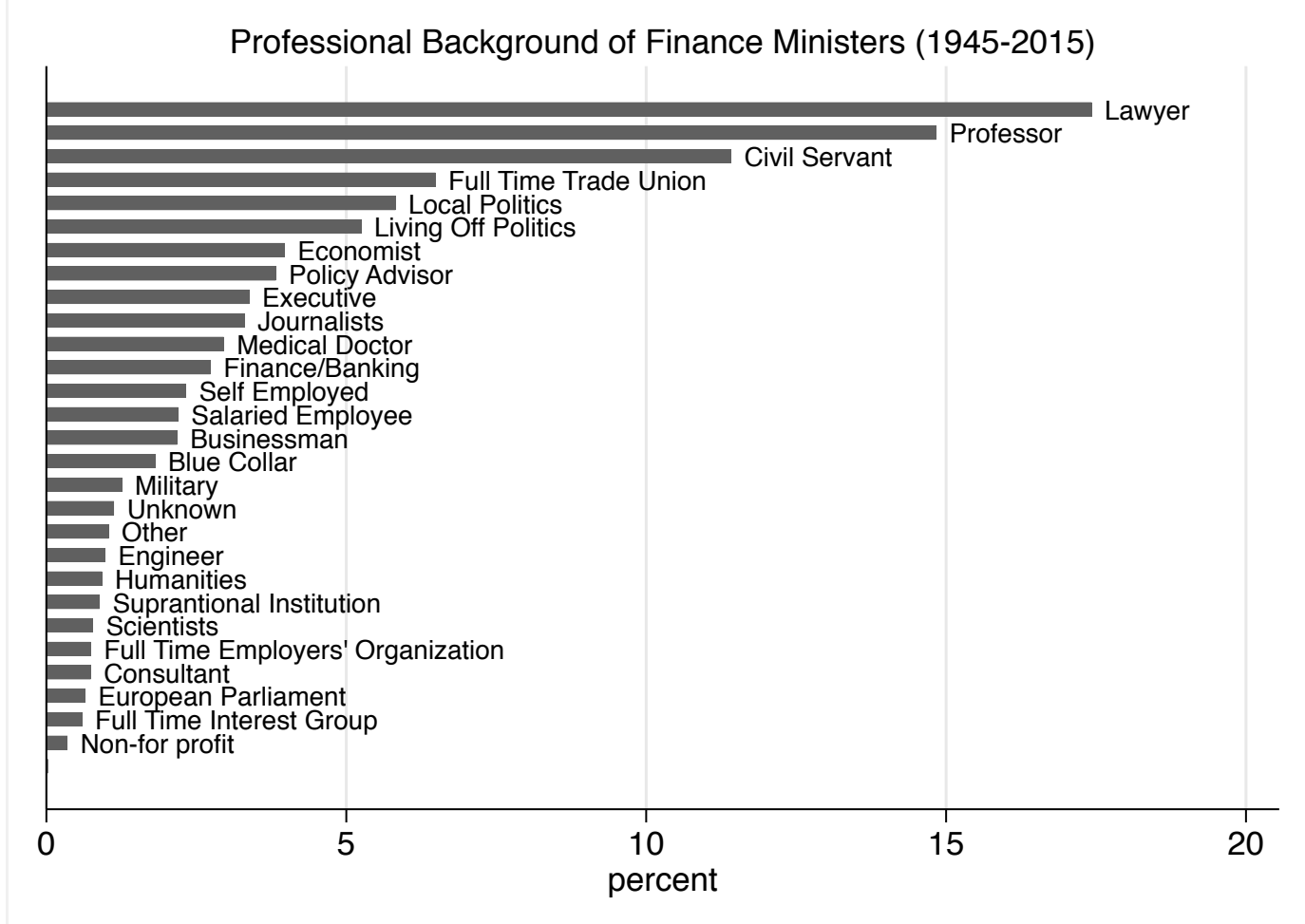

Using ministers' professional background as a proxy for their policy preferences (Alexiadou 2016; Chwieroth 2007; Kaplan 2017) we can reasonably assume that technocrats appointed to the finance portfolio are very likely to have strong, market-conforming policy preferences. This assumption is mostly supported by existing literature. While there is a debate on the role of technocrats and their ideology within the literature, for most, technocrats have clear promarket preferences (Santiso 2003; Dargent 2015).

To sum up, while we cannot a priori identify a particular ideological leaning for technocrats on the left-right dimension, we expect they have clear policy preferences based on their education and professional background. Therefore, to identify the policy preferences of technocrats we rely on their professional background just like we would do with elected politicians. However, what distinguishes technocrats from partisans or technopols is their 
commitment to a policy and in turn perhaps the intensity of their policy preferences compared to partisan experts. The crucial question, however, is even in the presence of commitment, why would technocrats be able to influence policy in line with their own policy preferences? I address this question next.

\section{Technocrats’ Policy Influence}

Unfortunately, the literature on the policy effects of technocrats is limited. McDonnell and Valbruzzi (2014) find that technocratic-led governments are associated with neo-liberal labour market reforms in Europe. Yet, there only have been 13 such governments during periods of grave economic or political instability. The only large-n empirical evidence regarding the policy effects of technocrat finance ministers is provided in a conference paper by Alexiadou and Gunaydin (2015). Using data from 13 West European, they find that technocrat ministers of finance are associated with cuts in social spending. This result is robust to a number of specifications and holds even after controlling for the presence of financial crises as well as a battery of other controls. Yet, the question remains to what extent are technocrats' neoliberal policy effects an outcome of their own policy preferences or of voters who are faced with major financial crises.

Although within the large literature on economic and political transitions in Latin America, we find more extensive accounts of the role of technocrats, most studies are limited to specific country-cases (Dominguez 1997; Joignant 2011; Dargent 2015). An exception is a recently published article by Kaplan (2017) who studies the appointments and policy effects of economic advisors across sixteen Latin American countries since the nineteen sixties. Even though Kaplan (2017) uses the broader definition of technocrats as all cabinet ministers, executive advisors and central bank governors, his work is unique in that it is the first large-n 
study on the policy effects of economists. Furthermore, Kaplan (2017) distinguishes technocrats as orthodox and heterodox economists. He finds that orthodox economists are more likely to be appointed during periods of economic downturns, mostly by left-leaning cabinets that need to appear as credible reformers. In turn, these orthodox economists are associated with fiscal contractions. In contrast, during good economic times, left-wing governments are more likely to appoint heterodox economists who are more concerned about economic growth than about economic stability.

\section{Expertise}

Kaplan's work is in agreement with other work that advances the argument that pro-market technocrats are appointed to lend credibility to governments. Governments achieve higher credibility by appointing technocrats for two main reasons: their expertise and their clearmarket conforming policy preferences. According to these accounts then (Dargent 2015; Santiso 2003), technocrats are appointed for their expertise and credibility, even when their policy preferences do not align with the president's. The more presidents rely on technocrats' expertise to deliver positive economic results that are electorally beneficially, the more likely their appointments are.

Under the principal-agent framework, as long as policy reforms advance presidents' political goals, they will appoint technocrats to deliver the reforms (Geddes 1990). However, principal-agent accounts have been challenged by illustrating that technocrats' expertise provides political goods that go beyond and are even independent of policy outcomes. Dargente (2015) explicitly deals with the question of the source of technocratic power. The author asks: "is their power derived from other actors or do they enjoy autonomy?" $\mathrm{He}$ studies the role of expert appointees - whether they are ministers or advisors in executive 
bodies, but not permanent bureaucrats- in Colombia and Peru over decades, and finds that they have a significant policy effect that goes well beyond the policy mandates given to them by the politicians who appoint them. For Dargent (2015) technocrats' source of power is their expertise and politicians' dependence on that expertise for electoral reasons. He illustrates that once technocratic teams are formed, they manage to entrench themselves in the agencies they are appointed, even though their appointments are not permanent. "Experts frequently use their knowledge to purposively exclude less-technically trained actors from policymaking, divert political and socioeconomic pressures, build informal and formal institutions that guarantee their positions' stability, and form alliances with other actors to advance their technical preferences. Through these strategies, experts actively aim to build technocratic autonomy and achieve continuity in their positions" (Dargent 2015).

One might wonder how generalizable Dargent's findings are. After all, governments' need for expertise varies significantly by the level of expertise within their permanent bureaucracies, the complexity of the policy as well as by the state of the economy. For example, most rich, industrialized countries have professional and extensive bureaucracies. Nonetheless, even within Europe, expertise is also considered central in appointing technocrat ministers due to the increasingly complex policy environment created by European integration (Bäck et al. 2009) and the lack in expertise within parliamentary groups (Yong and Hazell 2011).

Commitment to market conforming policies during economic crises

Expertise is often linked to another, more political and consequential motive for appointing technocrats. Presidents or prime ministers' need to commit to a certain set of policies. Particularly during economic crises, presidents or prime ministers are pressed to signal to 
voters and investors their policy intentions. For example, in Latin America presidents have had to commit to voters that their use of patronage will be drastically reduced (Magaloni 2006). One way of doing that is by delegating policy to technocrats. Committing to investors has also been an equally important problem for presidents. According to Santiso (2003), appointing pro-market friendly technocrats are crucial for gaining investor confidence. According to Schneider (1998), presidents become dependent on technocrats as long as investor confidence is necessary for positive electoral results. Once economic conditions improve, presidents do not need technocrats and technocrats, in turn, cease to control policy. Unfortunately, while these case-based accounts are enlightening, we lack systematic large-n evidence outside Latin America on the role of technocrats during and outside financial crises. Even more importantly the theory behind the role of technocrats as commitment devises raises important questions. If technocrats are appointees, how can they commit prime ministers and presidents to any sort of policy action?

\section{Questions for Future Research}

Managing economic expectations is crucial in politics, and even more so during periods of economic crises. Citizens and markets form expectations regarding the abilities and intentions of newly elected government. Will they deliver their policy announcements? Will they manage the economy successfully? In turn, these expectations affect voters' and, primarily, investors' decisions to trust or not, a government and its debt. While in most economically advanced democracies investors are confident that governments will honour their debt obligations, that confidence is often absent towards emerging economies but it also can be shaken when the economies of rich countries suffer major shocks that lead to high levels of unemployment and higher debt (Reinhart and Rogoff 2009). This is what happened during the 2008 financial crisis in Europe, for example. Not just smaller countries, like 
Greece or Portugal, but also major economic powers, such as Italy and France saw the interest rates on their government bonds rise dramatically.

Governments have several ways of addressing problems of credible commitment, namely that their policy announcements at time $t$ will be delivered at time $t+1$. Delegating policy to an independent bureaucrat is the best-known solution for making a credible commitment. The de-politicisation of monetary policy rests on the assumption that bureaucrats have long-term horizons whereas politicians are tempted to use monetary policy for short-term political gain, creating political business cycles (Alberto and Summers 1993). The delegation of monetary policy to politically independent central banks was historically motivated by the need to shape anti-inflationary expectations that would lead to a more optimal and stable macroeconomic policy (Bodea and Hicks 2015; Bodea and Higashijima 2017). When it comes to fiscal policy, however, delegation is more problematic and in fact delegation to independent bureaucrats is not possible.

Fiscal policy has direct distributive and redistributive effects, and while everyone agrees with the goals of low unemployment and high growth, not everyone agrees on how to achieve them (Alesina and Tabellini 2007, 2008). Probably the most radical political response to increasing the fiscal credibility of governments is the establishment of fiscal rules such as those imposed by the European Union. Although compliance to the EU's fiscal rules has historically been uneven, the 2009 debt and financial crisis saw many indebted member states stipulate explicit fiscal targets in their constitution significantly reducing their spending discretion. Moreover, in 2012 the vast majority of the EU member states signed the European Fiscal Compact which renews their commitment to balanced budgets and strengthens the role of monitoring institutions (Doray-Demers and Foucault 2017). 
Nonetheless, across the industrialized European democracies, perhaps the most successful mechanism of commitment to specific fiscal targets and policies is writing extensive government programs, also known as coalition agreements. Coalition agreements often set fiscal targets that are monitored by the government and provide a strong commitment mechanism to reduce public deficit (Hallerberg 2004; Hallerberg, Strauch, and Hagen 2009). Coalition agreements not only provide concrete information regarding the government's policy intentions but are also commitment mechanisms to the extent that the coalition partners police each other in upholding the agreement (Kluver and Back 2017). This might explain why investors are more trusting of coalition governments than of single party governments, despite their slower decision-making processes (Breen and McMenamin 2013; Sattler 2013).

Yet, not all governments can form stable multiparty coalitions particularly during periods of major economic and financial turbulence. Since 2009, many European governments, especially those that lack multiple institutional and partisan veto players resembled more to Argentina than to Germany. Particularly south European countries sought to increase their credibility towards the markets by appointing technocrats (Roberts 2017; Alexiadou and Gunaydin 2015). Despite the fact that appointing strong partisan finance ministers to safeguard the government's budget and cut public debt has been a common practice in single party governments (Hallerberg 2004), the appointments of technocrats to the top economic positions in the government are uncommon. What have the policy effects, if any, of these appointments been? Have they adopted reforms with lasting policy effects? Are these appointments the result of voters' discontent with partisan politics and an alternative to party government (Caramani 2017; Bertsou and Pastorella 2017)? Do technocratic appointments 
signal the beginning of the weakening of party government in ways that resemble the postcrises political systems of Latin American countries (Roberts 2017)?

Before closing this essay, I should also caution the reader as to the potential similarities in the role of technocrats across political systems and continents. Technocratic appointments are not as simple as they might at first look. Appointing an outside expert to the most consequential post in government carries serious implications for prime ministers. Fundamental differences exist between the presidential systems of Latin America and the parliamentary and semipresidential systems of Europe. If appointing a technocrat sends a strong signal to voters and markets, then deselecting her sends an even stronger signal of policy reversal. Thus we, as a discipline, need to further study and develop theories of ministerial selection and of technocratic appointments that do not rely on theories that emerged in presidential democracies.

Not only the organization of political power varies between presidential and parliamentary systems, but also politicians' career concerns. In presidential systems, non-partisans and technocrats are common (Amorim and Samuels 2010). Their appointments do not have a direct effect on representation since the members of parliament are the primary law makers. In contrast, in parliamentary systems the vast majority of finance and economic ministers, are elected and have constituencies. Unlike elected politicians, technocrats have not made commitments to voters, and their professional career is not subject to voter approval (Blondel 1991; Grossman 2014; Drazen and Ozbay 2015). Consequently, it is very likely that the appointment of technocrats in parliamentary systems have larger economic and political effects compared to presidential systems. 


\section{References}

Accetti, Carlo Invernizzi. 2016. America's choice this November is between a populist and a technocrat. The Guardian, 5 October 2016.

Adolph, Christopher. 2013. Bankers, Bureaucrats, and Central Bank Politics: the myth of neutrality Cambridge Studies in Comparative Politics. New York: Cambridge University Press.

Alberto, Alesina, and Lawrence H. Summers. 1993. Central Bank Independence and Macroeconomic Performance: Some Comparative evidence. Journal of Money, Credit and Banking 25 (2):151-162.

Alesina, Alberto, and Guido Tabellini. 2007. Bureaucrats or Politicians? Part I: A Single Policy Task. American Economic Review 97 (1):169-179.

- - . 2008. Bureaucrats or politicians? Part II: Multiple policy tasks. Journal of Public Economics 92:426-447.

Alexiadou, Despina. 2015. Ideologues, Partisans and Loyalists: Cabinet Ministers and Social Welfare Reform in Parliamentary Democracies. Comparative Political Studies 48:1051-1086.

- - . 2016. Ideologues, Partisans and Loyalists: Ministers and Policy-Making in Parliamentary Cabinets. Oxford: Oxford University Press.

Alexiadou, Despina, and Hakan Gunaydin. 2015. Selecting the right minister: The appointments and policy effects of technocrat and expert ministers. In Midwest Political Science Association. Chicago.

Amorim, Octavio, and David Samuels. 2010. Democratic Regimes and Cabinet Policis: A Global Perspective. Revista Ibero-Americana de Estudos Legislativos 1 (1):10-23.

Bäck, Hanna, Marc Debus, and Wolfgang C. Müller. 2016. Intra-party diversity and ministerial selection in coalition governments. Public Choice 166:355-378.

Bäck, Hanna, Patrick Dumont, Henk Erik Meir, Thomas Persson, and Kåre Vernby. 2009. Does European Integration Lead to a 'Presidentiazation' of Executive Politics? European Union Politics 10 (2):226-252.

Bergman, Torbjorn, Wolfgang C. Muller, Kaare Strom, and Magnus Blomgren. 2003. Democratic Delegation and Accountability: Cross-national Patterns. In Delegation and Accountability in Parliamentary Democracies, edited by K. Strom, W. C. Muller and T. Bergman. Oxford: Oxford University Press.

Berman, Sheri. 2017. Populism is a Problem. Elitist Technocrats Aren't the Solution. Foreign Policy, December 202017.

Bertsou, Eri, and Giulia Pastorella. 2017. Technocratic attitudes: a citizens' perspectives of expert decision-making. West European Politics 40 (2):430-458.

Bickerton, Christopher, and Carlo Invernizzi Accetti. 2017. Populism and technocracy: opposites or complements? Critical Review of International Social and Political Philosophy 20 (2):186-206.

Blondel, Jean. 1991. Cabinet Government and Cabinet Ministers. In The Profession of Government Minister in Western Europe, edited by J. Blondel and J.-L. Thiebault. London: Macmillan. 
Bodea, Cristina, and Raymond Hicks. 2015. Price stability and central bank independence: Discipline, credibility, and democratic institutions. International Organization 69 (1):35-61.

Bodea, Cristina, and Masaaki Higashijima. 2017. Central Bank Independence and Fiscal Policy: Can the Central Bank Restrain Deficit Spending. British Journal of Political Science 47 (1):47-70.

Bovens, Mark, and Anchrit Wille. 2017. Diploma Democracy: The Rise of Political Meritocracy. Oxford: Oxford University Press.

Breen, Michael, and lain McMenamin. 2013. Political Institutions, Credible Commitment and Sovereign Debt in Advanced Economies. International Studies Quarterly 57:842-854.

Buckley, Neil. 2016. Technocracy the only hope for lasting reform, says ex-minister. Financial Times, 7 February 2016.

Camerlo, Marcelo, and Anibal Perez-Linan. 2015. The Politics of Minister Retention in Presidential Systems: Technocrats, Partisans, and Government Approval. Comparative Politics 47 (3):315-333.

Caramani, Daniele. 2017. Will vs Reason: The Populist and Technocratic Forms of Political Representation and Their Critique to Party Government. American Political Science Review 111 (1):54-67.

Christensen, Johan. 2017. The Power of Economists within the State. Stanford, California: Stanford University Press.

Chwieroth, Jeffrey. 2007. Neoliberal Economists and Capital Account LIberalization in Emerging Markets. International Organization 61:443-463.

Dargent, Eduardo. 2015. Technocracy and Democracy in Latin America. New York: Cambridge University Press.

Dominguez, Juan I. 1997. Technopols: Freeing Politics and Markets in Latin America in the 1990s. University Park: Pennsylvania State University Press.

Doray-Demers, Pascal, and Martial Foucault. 2017. The Politics of fiscal rules within the European Union: a dynamic analysis of fiscal rules stringency. Journal of European Public Policy 24 (6):852-870.

Dowding, Keith, and Patrick Dumont, eds. 2009. The selection of Ministers in Europe: Hiring and Firing. New York: Routledge.

Drazen, Allan, and Erkut Y. Ozbay. 2015. Does "Being Chosen to Lead" Induce Non-Selfish Behavior? Experimental Evidence on Reciprocity. University of Maryland.

Fischer, Frank. 1990. Technocracy and the Politics of Expertise. Newbury Park: Sage.

Fourcade, Marion. 2009. Economists and Societies: Discipline and Profession in the United States, Britain, and France, 1890s to 1990s. Princeton, NJ: Princeton University Press.

Geddes, Barbara. 1990. Building 'Stata' Autonomy in Brazil, 1930-1964. Comparative Politics 22 (2):217-235.

Grossman, Guy. 2014. Do Selection Rules Affect Leader Responsiveness? Evidence from Rural Uganda. Quarterly Journal of Political Science 9 (1):1-44.

Hallerberg, Mark. 2004. Domestic Budgets in a United Europe: Fiscal Governance from the end of Bretton Woods to EMU. Ithaca: Cornell Univeristy Press.

Hallerberg, Mark, Rolf Rainer Strauch, and Jurgen Von Hagen. 2009. Fiscal Governance in Europe. New York: Cambridge University Press.

Hallerberg, Mark, and Joachim Wehner. 2017. When do you get economists as policymakers? British Journal of Political Science. 
Harford, Tim. 2017. Some things are best left to the technocrats. Financial Times, 17 March 2017.

Jochimsen, Beate, and Sebastian Thomasius. 2014. The perfect finance minister: Whom to appoint as finance minister to balance the budget. European Journal of Political Economy 34:390-480.

Joignant, Alfredo. 2011. The Politics of Technopols: Resources, Political Competence and Collective Leadership in Chile, 1990-2010. Journal of Latin American Studies 43 (3):517-546.

Jopson, Barney. 2017. With alumni in the White House, Goldman sees an opening. Financial Times, 22 August 2017.

Kaplan, Stephen B. 2017. Partisan technocratic cycles in Latin America. Electoral Studies 45:219-229.

Kluver, Heike, and Hanna Back. 2017. Coalition agreements, issue coverage and cabinet governance. In Midwest Political Science Association. Chicago.

Magaloni, Beatriz. 2006. Voting for Autocracy: Hegemonic Party Survival and Its Demise in Mexico. Cambridge: Cambridge University Press.

Martinez-Gallardo, Cecilia, and Petra Schleiter. 2015. Choosing Whom to Trust: Agency Risks and Cabinet Partisanship in Presidential Democracies. Comparative Political Studies 48 (2):231-264.

McDonnell, Duncan, and Marco Valbruzzi. 2014. Defining and classifying technocrat-led and technocratic governments. European Journal of Political Research 53 (4):654-671.

Meynaud, Jean. 1964. La technocratie. Mythe ou réalité. Paris: Payot.

OECD. 2010. OECD Employment and Labour Market Statistics. In Labour market programmes: expenditure and participants. Paris.

Pastorella, Giula. 2016. Technocratic Governments in Europe: Getting the Critique Right. Political Studies 64 (4):948-965.

Pinto, António Costa, Maurizio Cotta, and Pedro Tavares de Almeida, eds. 2017. Technocratic Ministers and Political Leadership in European Democracies. London: Palgrave Macmillan.

Rampell, Catherine. 2011. Depegating Economic Policy to the Techncorats, and Away from Democracy. New York Times, 26 September 2011.

Reinhart, Carmen M., and Kenneth S. Rogoff. 2009. This Time is Different: Eight Centuries of Financial Folly. Princeton.

Roberts, Kenneth. 2017. State of the Field: Party politics in hard times. European Journal of Political Economy 56 (2):218-233.

Rosanvallon, Pierre. 2011. Democratic Legitimacy: Impartiality, Reflexivity, Proximity. Princeton, New Jersey Princeton University Press.

Santiso, Javier. 2003. The political economy of emerging markets, CERI. New York: Palgrave Macmillan.

Sattler, Thomas. 2013. Do Markets Punish Left Governments? . Journal of Politics 75 (2):343356.

Savage, Luke. 2017. Twilight of the Technocrats? . Jacobin, 23 February 2017.

Schneider, Ben Ross. 1998. The Material Basis of Technocracy: Investor Confidence and Neoliberalism in Latin America. In The Politics of Expertise in Latin America, edited by M. A. Centeno and P. Silva. New York: Macmillan Press.

Strom, Kaare. 2000. Delegation and Accountability in Parliamentary Democracies. European Journal of Political Research 77:261-289. 
Yong, Ben, and Robert Hazell. 2011. Putting Goats Amongst the Wolves: Appointing Ministers from Outside the Parliament, The Constitution Unit, UCL, London. 